University of Nebraska - Lincoln

DigitalCommons@University of Nebraska - Lincoln

Spring 2010

\title{
Taiwanese Industry Competitiveness when Outward FDI is Defensive
}

\author{
Ling Sun \\ ERS, USDA, slwang@ers.usda.gov \\ Lilyan E. Fulginiti \\ University of Nebraska, Ifulginiti1@unl.edu \\ Yo-Chan Chen \\ Providence University
}

Follow this and additional works at: https://digitalcommons.unl.edu/ageconfacpub

Part of the Agricultural and Resource Economics Commons, and the Growth and Development Commons

Sun, Ling; Fulginiti, Lilyan E.; and Chen, Yo-Chan, "Taiwanese Industry Competitiveness when Outward FDI is Defensive" (2010). Faculty Publications: Agricultural Economics. 100.

https://digitalcommons.unl.edu/ageconfacpub/100

This Article is brought to you for free and open access by the Agricultural Economics Department at DigitalCommons@University of Nebraska - Lincoln. It has been accepted for inclusion in Faculty Publications: Agricultural Economics by an authorized administrator of DigitalCommons@University of Nebraska - Lincoln. 
Provided for non-commercial research and education use. Not for reproduction, distribution or commercial use.

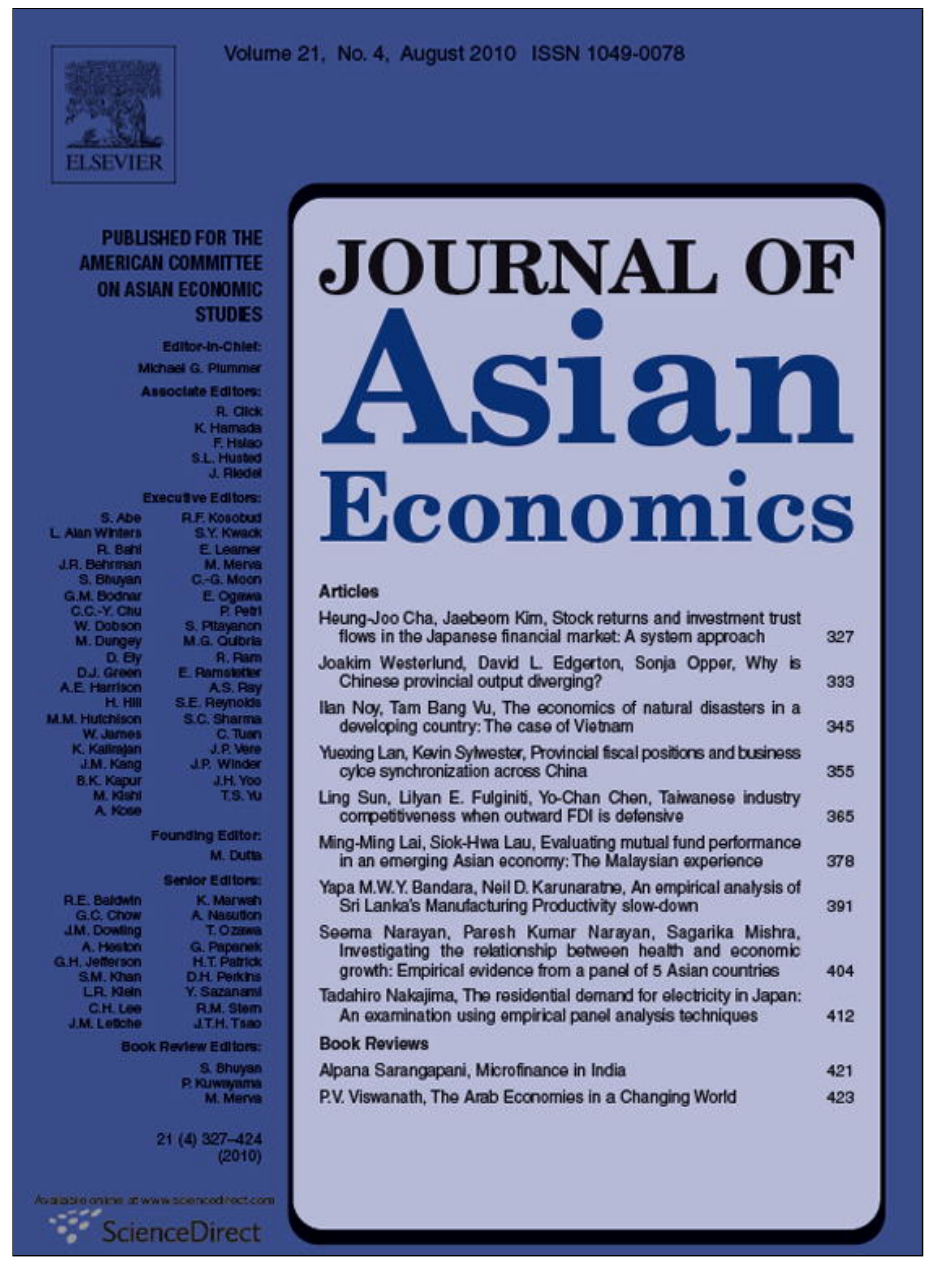

This article appeared in a journal published by Elsevier. The attached copy is furnished to the author for internal non-commercial research and education use, including for instruction at the authors institution and sharing with colleagues.

Other uses, including reproduction and distribution, or selling or licensing copies, or posting to personal, institutional or third party websites are prohibited.

In most cases authors are permitted to post their version of the article (e.g. in Word or Tex form) to their personal website or institutional repository. Authors requiring further information regarding Elsevier's archiving and manuscript policies are encouraged to visit:

http://www.elsevier.com/copyright 


\title{
Taiwanese industry competitiveness when outward FDI is defensive
}

\author{
Ling Sun ${ }^{\mathrm{a}, *}$, Lilyan E. Fulginiti ${ }^{\mathrm{b}}$, Yo-Chan Chen ${ }^{\mathrm{c}}$ \\ ${ }^{a}$ Economic Research Service, USDA, United States \\ ${ }^{\mathrm{b}}$ University of Nebraska-Lincoln, United States \\ ${ }^{\mathrm{c}}$ Providence University, Taiwan
}

\section{A R T I C L E I N F O}

\section{Article history:}

Received 28 January 2009

Received in revised form 4 November 2009

Accepted 7 February 2010

\section{JEL classification:}

010

033

047

Keywords:

Productivity

Competitiveness

Malmquist Index

Outward FDI

Defensive Outward FDI

Expansionary Outward FDI

\begin{abstract}
A B S T R A C T
The main purpose of this study is to examine the links between outward FDI and the competitiveness of Taiwanese industries. This is done by emphasizing the difference between 'defensive' versus 'expansionary' outward FDI. The empirical study is based on a panel data of 15 industries over the period 1991-2001. The results indicate that outward FDI of the defensive type, in particular that destined to China, while increasing industry efficiency has had a significant negative influence on competitiveness of the Taiwanese industry through its effects on innovative activity. While outward FDI has impacted the industry's productivity growth it has not decreased the industry's output growth or its share of domestic GDP.
\end{abstract}

Published by Elsevier Inc.

\section{Introduction}

Openness as a channel of international technology spillover has been widely documented in the last decade. The contributions of trade flows and inward FDI (foreign direct investment) to technological progress have attracted the attention of academics (Brooks, Roland-Holst, \& Zhai, 2008; Edwards, 1993, 1998; Frankel \& Romer, 1999; Grossman \& Helpman, 1990; Hsiao \& Hsiao, 2006; Makki \& Somwaru, 2004; Ng and Tuan, 2006; Oxelheim \& Ghauri, 2008; Yanikkaya, 2003, among others). But there is still lack of agreement on the relationship between outward FDI and home industry's international competitiveness. Some suggest that overseas production might generate employment or foster exports in the home country (Blomström, Fors, \&Lipsey 1997; Lipsey, 1994; Lipsey, Ramstetter, \& Blomstrom, 2000, etc.). Some propose that outward FDI may strengthen the viability and competitiveness of domestic industries (Chen \& Ku, 2000; Tejima, 2000) or move along with export and output shares rather than as substitutes (Nachum, Jones, \& Dunning, 2001). However, some treat outward FDI as synonymous with capital flight or job export and fear that it has an adverse effect on home employment as well as long-run competitiveness of domestic industries or that it might even generate a "hollowing out" effect for home industries (Frank \& Freeman, 1978; Glickman \& Woodward, 1989).

Outward FDI can be further distinguished into two categories, 'expansionary FDI' (Hymer, 1960; Caves, 1974) and 'defensive FDI' (Vernon, 1966). According to the widely adopted definition, when firms make an overseas investment in order

\footnotetext{
The views expressed are the authors and do not necessarily reflect those of the Economic Research Service or USDA

* Corresponding author.

E-mail address: slwang@ers.usda.gov (L. Sun).
} 
to exploit the firm-specific advantage embodied in their intangible asset, it can be classified as an 'expansionary FDI'. When firms relocate their financial funds in low-wage countries to reduce labor costs, it can be viewed as a 'defensive FDI'. Since there is still much controversy on the role of outward FDI in the home country's productivity growth and in the home industry's competitiveness, our main interest in this study is to examine the dynamic links between outward FDI and home industries' competitiveness in Taiwan.

The literature is not clear on the concept of competitiveness. In this paper we use three different concepts found in the economics and business literature to represent the concept of competitiveness. The first one approximates changes in competitiveness with changes in industries' total factor productivity (TFP) growth. We calculate TFP at the industry level and decompose productivity change into technical change or innovations, and efficiency change. This decomposition is useful when studying expansionary versus defensive FDI. A second, more conventional approximation, makes changes in competitiveness synonymous with changes in industries' real GDP growth rates. Finally, a third approach, more akin to Porter's competitiveness concept and the business literature, looks at changes in industries' shares of GDP. The more productivity grows, the industry's GDP grows, or its GDP share grows, the more competitive the industry is. The objective of this study is to understand the relationship between competitiveness and expansionary and defensive outward FDI.

\section{Measurement of productivity change}

Studies on the effect of FDI or trade flows on economic growth typically employ a TFP index under an efficient production assumption and use cross-section analysis. Unknown improvements in efficiency may overstate the measure of technological progress. Instead of a cross-section analysis Edwards (1993) suggests that studies of the relationship between openness and output growth "require more detailed analysis relying, at least in part, on time-series data." (p. 1385) In this study we pool time series and cross-sectional data and we combine econometric analysis with information obtained from a methodology that allows decomposition of productivity change into technical and efficiency change. This methodology provides information that would help understand the impact of FDI on industrial productivity change but also on its effect on individual efficiency performance. The Malmquist Index is a nonparametric, nonstochastic index that allows such decomposition by identifying a global frontier and measuring not only shifts of that frontier but also changes in the distance between individual units and the best practice frontier.

Caves, Christensen, and Diewert (1982a) and Caves, Christensen, and Diewert (1982b) extended Malmquist (1953) and Moorsteen (1961) concepts and develop a productivity measure between two discrete time periods based on input and output distance functions. This index is the Malmquist productivity index defined as the ratio of two distance functions. ${ }^{1}$

Färe et al. (1992) and Färe, Shawna, Mary, and Zhongyang (1994) further showed how to decompose the Malmquist Index into two components, technical change and efficiency change, and proposed linear programming, Data Envelopment Analysis (DEA), to calculate the distance functions component of the Malmquist Productivity index. They further decomposed the efficiency change into pure efficiency change, and scale efficiency change; allowing a variable returns to scale (VRS) technology.

Following Caves et al. (1982a, 1982b) and Färe et al. (1989) and Färe, Shawna, et al. (1994), we define an output-based Malmquist productivity index as a geometric mean of two output distance functions. We first need to calculate the output distance function for each time period. The output (o) distance function is defined as:

$D_{o}^{t}\left(x^{t}, y^{t}\right) \equiv \inf \left\{\theta:\left(x^{t}, y^{t} / \theta\right) \in S^{t}\right\}$

For each time period, the production technology is given by the production possibility set $S^{t}$; and $\mathbf{x}^{t}$ and $\mathbf{y}^{t}$ are inputs vector and outputs vector, respectively. The output distance function measures the proportion by which observed output can be expanded, given inputs, to reach frontier output, shown as Oa/Ob in Fig. 1. It is the reciprocal of Farrell's (1957) efficiency measures. The production plan $\left(\mathbf{x}^{t}, \mathbf{y}^{t}\right)$ is feasible (on the frontier or in the technology set) when $D_{o}^{t}\left(x^{t}, y^{t}\right)=1$ or $\langle 1$. $\left.D_{o}^{t}\left(x^{t}, y^{t}\right)\right\rangle 1$ is not feasible under the technology $S^{t}$.

The output distance function in time period $t+1$ is:

$D_{o}^{t+1}\left(x^{t+1}, y^{t+1}\right) \equiv \inf \left\{\theta:\left(x^{t+1}, y^{t+1} / \theta\right) \in S^{t+1}\right\}$

To obtain the Malmquist TFP change index we need to redefine two output-distance-functions with mixed time periods.

$D_{o}^{t+1}\left(x^{t}, y^{t}\right) \equiv \inf \left\{\theta:\left(x^{t}, y^{t} / \theta\right) \in S^{t+1}\right\}$

$D_{o}^{t}\left(x^{t+1}, y^{t+1}\right) \equiv \inf \left\{\theta:\left(x^{t+1}, y^{t+1} / \theta\right) \in S^{t}\right\}$

\footnotetext{
1 They show that when the technology is represented by a translog form with constant second order terms and firms are optimizers, the Malmquist productivity index is shown to be equivalent to the Tornqvist index. The Tornqvist index assumes technical and allocative efficiency while this is not necessary for the Malmquist index calculation.
} 


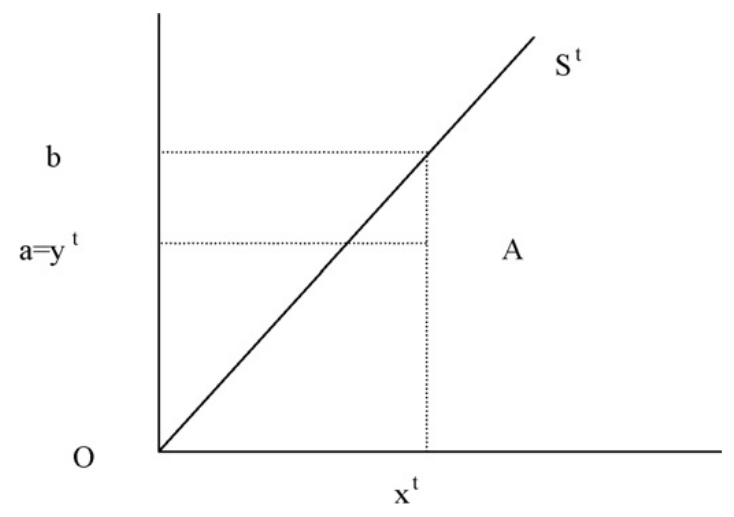

Fig. 1. Measurement of output distance.

$D_{o}^{t+1}\left(x^{t}, y^{t}\right)$ measures the output distance for $\left(x^{t}, y^{t}\right)$ under the technology at time period $t+1 . D_{o}^{t+1}\left(x^{t+1}, y^{t+1}\right)$ measures the output distance for $\left(x^{t+1}, y^{t+1}\right)$ under the technology at time period $t$. Both are hypothetical.

According to Caves et al. (1982a, 1982b), the output-based Malmquist productivity change index with respect to a certain technology is:

$M_{o}^{t}=\frac{D_{o}^{t}\left(x^{t+1}, y^{t+1}\right)}{D_{o}^{t}\left(x^{t}, y^{t}\right)}$

$M_{o}^{t+1}=\frac{D_{o}^{t+1}\left(x^{t+1}, y^{t+1}\right)}{D_{o}^{t+1}\left(x^{t}, y^{t}\right)}$

Färe et al. (1989) redefined a Malmquist-type productivity index using the geometric mean of these two output:

$M_{o}\left(x^{t+1}, y^{t+1}, x^{t}, y^{t}\right)=\left[\frac{D_{o}^{t}\left(x^{t+1}, y^{t+1}\right)}{D_{o}^{t}\left(x^{t}, y^{t}\right)} \frac{D_{o}^{t+1}\left(x^{t+1}, y^{t+1}\right)}{D_{o}^{t+1}\left(x^{t}, y^{t}\right)}\right]^{1 / 2}$

With some manipulation, (2-7) can be rewritten as:

$M_{o}\left(x^{t+1}, y^{t+1}, x^{t}, y^{t}\right)=\frac{D_{o}^{t+1}\left(x^{t+1}, y^{t+1}\right)}{D_{o}^{t}\left(x^{t}, y^{t}\right)}\left[\frac{D_{o}^{t}\left(x^{t+1}, y^{t+1}\right)}{D_{o}^{t+1}\left(x^{t+1}, y^{t+1}\right)} \frac{D_{o}^{t}\left(x^{t}, y^{t}\right)}{D_{o}^{t+1}\left(x^{t}, y^{t}\right)}\right]^{1 / 2}$

The first term on the right-hand side of (2-8) represents the change in efficiency between periods $t$ and $t+1$, and the second term is the geometric mean of technical change. We can use Fig. 2 to demonstrate this decomposition. The efficiency change component can be represented as

$\frac{O c / O d}{O a / O b}=\frac{O c}{O d} \frac{O b}{O a}$

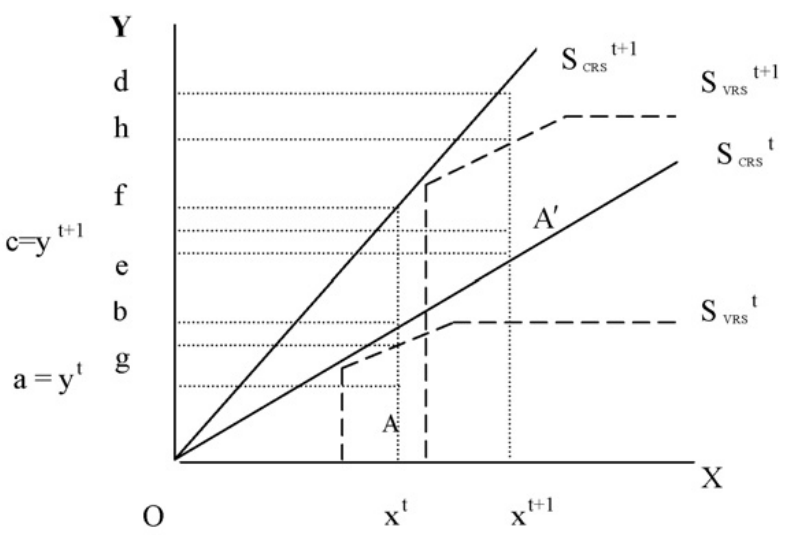

Fig. 2. Composition of Malmquist Index. 
The technical change component can be represented as

$$
\left[\frac{O c / O e}{O c / O d} \frac{O a / O b}{O a / O f}\right]^{1 / 2}=\left[\frac{O d}{O e} \frac{O f}{O b}\right]^{1 / 2}
$$

Technical change is regressive, is unchanged, or has improved when the technical change index is smaller, equal or larger than 1 . This is sometimes referred to as the 'innovation' effect. When the technical efficiency index is smaller, equal or larger than 1; technical efficiency has deteriorated, is unchanged or has improved. This is sometimes referred to as the 'catch up' effect.

According to Färe, Grosskopf, and Lovell (1994), efficiency change under the assumption of a constant returns-to-scale technology (CRS) can be further decomposed into scale efficiency change and pure efficiency change. The scale efficiency change is referred to as a scale change that brings the production closer or farther away from the optimum scale of output under a variable returns-to-scale (VRS) technology. Then the efficiency component in Eq. (2-8) can be decomposed as follows:

$\frac{D_{o}^{t+1}\left(x^{t+1}, y^{t+1}\right)_{\mathrm{CRS}}}{D_{0}^{t}\left(x^{t}, y^{t}\right)_{\mathrm{CRS}}}=\frac{D_{o}^{t+1}\left(x^{t+1}, y^{t+1}\right)_{\mathrm{VRS}}}{D_{o}^{t}\left(x^{t}, y^{t}\right)_{\mathrm{VRS}}}\left[\frac{D_{o}^{t}\left(x^{t}, y^{t}\right)_{\mathrm{VRS}}}{D_{o}^{t}\left(x^{t}, y^{t}\right)_{\mathrm{CRS}}} \frac{D_{o}^{t+1}\left(x^{t+1}, y^{t+1}\right)_{\mathrm{CRS}}}{D_{o}^{t+1}\left(x^{t+1}, y^{t+1}\right)_{\mathrm{VRS}}}\right]$

i.e., CRS efficiency change $=$ Pure efficiency change $\times$ Scale efficiency

We can also use Fig. 2 to demonstrate the composition of CRS efficiency change. The pure efficiency change can be represented as

$\frac{O c / O h}{O a / O g}=\frac{O c}{O h} \frac{O g}{O a}$

Scale efficiency change can be represented as

$\mathrm{Oc} / \mathrm{Od} \mathrm{Oa} / \mathrm{Og} \quad \mathrm{Oh} \mathrm{Ob}$

$\overline{\mathrm{Oc} / \mathrm{Oh}} \overline{\mathrm{Oa} / \mathrm{Ob}}=\overline{\mathrm{Od}} \overline{\mathrm{Og}}$

Values exceeding unity denote improvement for both pure efficiency change as well as scale efficiency change.

Linear programming is used to construct the best practice frontier from sample data then to obtain the distances to that frontier needed to calculate the indexes. This frontier is defined, in each time period, by those industries that are best performers. All other industries are then compared to this frontier during that time period and their efficiency is calculated using an output distance function. The frontier $S^{\mathrm{t}}$ is obtained from:

$S^{t}=\left\{\begin{array}{cc}\left(x^{t}, y^{t}\right): y_{m}^{k^{\prime}, t} \leq \sum_{k=1}^{K} \lambda^{k, t} y_{m}^{k^{\prime}, t}, & m=1, \ldots, M ; \\ \sum_{k=1}^{K} \lambda^{k, t} x_{n}^{k^{\prime}, t} \leq x_{n}^{k^{\prime}, t}, & n=1, \ldots, N ; \\ \lambda^{k, t} \geq 0, & k=1, \ldots, K\end{array}\right\}$

where $m$ are outputs, $n$ are inputs, $k$ are industries and $\lambda^{k, t}$ are the intensity variable for each observation in the process of constructing the technology frontier by taking linear combinations and radial contractions or expansions from the observed data. The output distance function for year $t$ is obtained as a solution to the following problem:

$$
\begin{array}{ll}
{\left[D_{o}^{t}\left(\boldsymbol{y}_{t}, \boldsymbol{x}_{t}\right)\right]^{-1}=} & \max _{\phi, \lambda} \phi \\
s t & -\phi \boldsymbol{y}_{i t}+\boldsymbol{Y}_{t} \lambda \geq 0, \\
& \boldsymbol{x}_{i t}-\boldsymbol{X}_{t} \lambda \geq 0, \\
& \lambda \geq 0,
\end{array}
$$

As Eq. (2-8) indicates, it is necessary to solve similar problems for three other distances for each pair of consecutive years, per industry. So we solve problems similar to (2-15) for the own period and mixed period distance functions defined in (2-1) to (2-4). To implement the scale efficiency decomposition in (2-11) we solve problems (2-14) and (2-15) for a VRS technology. This is done by modifying the restriction on the activity variable $\left(\sum_{k} \lambda^{k, t}=1\right)$. These problems were solved using the program DEAP (Coelli et al., 2005).

\section{Model and data}

\subsection{Model}

In this section we introduce models to capture the potential effect of different types of outward FDI on industries' competitiveness. As mentioned above, we consider three alternative concepts of competitiveness. Guided by the economics literature, competitiveness is alternatively proxied by industry output change and by productivity change. Following the business literature, we use the evolution of each industry's share of GDP to proxy competitiveness. 
From the standard treatment of endogenous growth models, we assume that productivity change (and alternatively output change) is a function of changes in the domestic stock of innovations and of the flow of innovations occurring through international knowledge spillover. The model can be written as:

TFPCH $=f_{1}\left(A_{d}, A_{f}\right)$

where TFPCH (the alternative model replaces it by output change) is the change in total factor productivity (TFP), $A_{d}$ is the change in domestic current stock of innovations and $A_{f}$ is the flow of innovations through international knowledge spillovers. We use changes in the stock of R\&D as a proxy for $A_{d}$. $A_{f}$ is assumed to be a function of outward FDI, trade flows, and inward FDI.

Eq. (3-2) is used to estimate the effect of outward FDI. The other variables on the right-hand side can be treated as control variables.

$\mathrm{TFPCH}_{t}=\alpha_{0}+\alpha_{1} \Delta \ln \mathrm{OFDI}_{t-1}+\alpha_{2} \Delta \ln I_{F D I_{t-1}}+\alpha_{3} \Delta \ln X_{t-1}+\alpha_{4} \Delta \ln M_{t-1}+\alpha_{5} \Delta \ln \mathrm{RE}_{t-1}+\Sigma_{j} \alpha_{6 j} D_{j}+\varepsilon_{t}$

where $\Delta$ represents differenced variables, $\ln$ is natural logarithm, OFDI is the flow of outward FDI, IFDI is the inflow FDI, $X$ is the flow of export, $M$ is the flow of imports, R\&D is the stock of research and development, and $D$ 's are industries' dummies, $j=1, \ldots, 14$. Lagged variables are used to capture dynamics and to avoid issues of simultaneity. Following Raut (1995) the stock of $R \& D$ is generated as:

$\mathrm{R} \mathrm{D}_{j, t}=\Sigma_{\tau=0}^{4}(1-d)^{\tau} E_{j t-\tau}$

where $E_{j t-\tau}$ are the expenses on $\mathrm{R} \& \mathrm{D}$ for industry $j$ at time $t-\tau$ and $d$ is the depreciation rate assumed to be $15 \%$. Since we would also like to examine effects from alternative categories of outward FDI, we divide it into expansionary outward FDI (OFDI_E), and defensive outward FDI (OFDI_D) depending on the destination of the capital flow. Capital destined to developed countries as well as other NIEs (newly industrialized economies) is taken as expansionary outward FDI. Capital destined to developing countries is considered defensive outward FDI. Since most of Taiwan's outward FDI in recent years has been destined to China, one of the models treats it separately-OFDI destined to China (OFDI_C) versus OFDI destined to other countries (OFDI_O).

In addition to modeling industry output growth and TFPCH we use additional information obtained from the Malmquist approach, the indexes reflecting technical and efficiency change, and model them separately in an attempt to uncover potentially important information. Is there any important relationship between expansionary FDI and the index of technical change? Could it be that defensive FDI is undertaken to improve industry efficiency rather than for innovation purposes? The Malmquist decomposition gives us a chance to look at these additional hypotheses. We also model the evolution of each industry's GDP share as literature on competitive advantage indicates that increased shares could reflect increased competitiveness.

The following is a list of dependent variables used: PECH is Pure Efficiency change; SECH is Scale Efficiency change; EFFCH is Efficiency change; TECHCH is Technical change; GDPCH is the real GDP growth rate of each industry; GDPSHCH is the GDP share change for each industry. The empirical study is based on panel data for 15 industries over the period 1991-2001.

Though theoretical studies support the positive relationship between openness and economic growth, there still exists controversy based on the empirics. Lawrence and Weinstein (1999) questioned the importance of Japanese exports as a source of productivity growth. They supported the conclusion of Rodrik (1999) that "export fetishism is unwarranted". Connolly (1998), Lichtenberg and Van Pottelsberghe de la Potterie (1996), and Haddad and Harrison (1993) did not detect a positive contribution from FDI inflows or from international R\&D spillovers, to productivity growth of domestic firms. Connolly pointed out that the quality of the FDI data might be responsible for some of these outcomes. Chang and Luh (2000) observed that FDI's could have positive contributions to technical change only when there exist sufficient educational background to facilitate absorption of advanced technologies from foreign investments by the domestic firms. Hsiao and Hsiao (2006) found that no generalizations were possible on this issue for eight Asian economies. We do not have any particular expectation on the sign of the variables of interest.

\subsection{Data}

The inputs we considered in the measurement of the Malmquist TFP index are capital $(\mathrm{K})$ and labor $(\mathrm{L})$. The labor input is the working hours for each industry. The data on capital is capital stock adjusted by the capital utilization rate to reflect true capital in use. Capital stock for each industry was obtained from the Directorate-General of Budget, Accounting and Statistics, Executive Yuan, Republic of China (2003) by using the benchmark extrapolation method based on the national wealth census information (1988).

Since inputs only include labor and capital and no intermediate inputs, it is more appropriate for us to utilize value-added output rather than total output in TFP measurement. Output for each manufacturing industry is the real value-added GDP, drawn from the Yearbook of Earnings and Productivity Statistics, Taiwan Area (2004). Inputs and outputs are in real terms in the original source. 
Data for exports and imports in each industry were drawn from the Monthly Statistics of Exports and Imports, Taiwan Area, The Republic of China. Both exports and imports were deflated using the import and export price indices respectively.

Data on FDI are the pre-approved foreign investment amounts reported by the Investment Commission, Ministry of Economic Affairs, Republic of China. Real FDI variables were obtained using the CPI index.

Industry R\&D expenses are drawn from Indicators of Science and Technology, Republic of China (2004.) The R\&D expenditures were deflated using the CPI index before being transformed into an R\&D stock following the method described in Eq. (3-3).

As different data sources used different industry classifications, we grouped the manufacturing sector into 15 main manufacturing industries and obtained consistent aggregations of real value added output, labor, capital stock and rates of capital utilization.

\section{The Malmquist Index for Taiwan's manufacturing sector}

The average Malmquist indices from 1992 to 2001 for each industry are shown in Table 1 . The Malmquist productivity change index (TFPCH) is decomposed into efficiency change (EFFCH) and technical change (TECHCH). Efficiency change $(\mathrm{EFFCH})$ is further separated into two factors-pure efficiency change (PECH) and scale efficiency change (SECH) as mentioned in Eqs. (2-8) and (2-11).

In Table 1 we can see that from 1992 to 2001 average TFP for each industry falls between 0.93 and 1.07 . As mentioned above, TFP larger than one indicates productivity improvement and smaller than 1 indicates the deterioration. Six industries show productivity increases of 0.3-6.85\%. These include Garment and Footwear, Leather and Fur Products, Electronic and Electric Appliances, Transport Equipment, and Precision Instruments. Positive contributions to TFP change are mainly attributed to technical change (TECHCH) with a $1.27 \%$ to $6.16 \%$ annual growth rate. On the other hand, efficiency was declining through time for most industries and was a main source of TFP deterioration. Negative efficiency change is attributed mainly to scale efficiency deterioration.

\section{Econometric results}

The econometric estimation was based on pooled time-series cross-section data for 15 industries covering the 19932001 period. The models were estimated incorporating corrections for autocorrelated errors within cross-sectional units. To allow for differences among industries we use a fixed effects approach and include cross-sectional dummy variables in estimation. The estimation was conducted using SHAZAM software.

To avoid generating spurious results due to unit roots the variables were first examined for stationarity and transformed by differencing if needed. We applied a panel unit root test developed by Im-Pesaran-Shin (2003) (hereafter, IPS) to examine each variable for stationarity. The IPS test is based on the average of individual Dickey-Fuller unit root tests.

Table 1

Decomposition of Malmquist Index (1992-2001).

\begin{tabular}{|c|c|c|c|c|c|c|c|c|c|c|}
\hline \multirow[t]{2}{*}{ Industries } & \multicolumn{2}{|c|}{$\begin{array}{l}\text { Productivity } \\
\text { change }\end{array}$} & \multicolumn{2}{|c|}{ Technical change } & \multicolumn{2}{|c|}{ Efficiency change } & \multicolumn{2}{|c|}{$\begin{array}{l}\text { Pure efficiency } \\
\text { change }\end{array}$} & \multicolumn{2}{|c|}{$\begin{array}{l}\text { Scale efficiency } \\
\text { change }\end{array}$} \\
\hline & TFPCH & $\begin{array}{l}\text { Change } \\
\text { rate }(\%)\end{array}$ & TECHCH & $\begin{array}{l}\text { Change } \\
\text { rate }(\%)\end{array}$ & EFFCH & $\begin{array}{l}\text { Change } \\
\text { rate (\%) }\end{array}$ & $\mathrm{PECH}$ & $\begin{array}{l}\text { Change } \\
\text { rate }(\%)\end{array}$ & $\mathrm{SECH}$ & $\begin{array}{l}\text { Change } \\
\text { rate (\%) }\end{array}$ \\
\hline Food and beverage & 0.9289 & -7.11 & 0.9257 & -7.43 & 1.0031 & 0.31 & 1 & 0 & 1.0034 & 0.34 \\
\hline Textile mill & 0.9909 & -0.91 & 0.9963 & -0.37 & 0.9948 & -0.52 & 0.9948 & -0.52 & 0.9998 & -0.02 \\
\hline Garment and footwear & 1.0436 & 4.36 & 1.0454 & 4.54 & 0.9985 & -0.15 & 0.9987 & -0.13 & 0.9996 & -0.04 \\
\hline Leather and fur products & 1.0198 & 1.98 & 1.0229 & 2.29 & 0.997 & -0.3 & 0.99 & -0.11 & 0.9979 & -0.21 \\
\hline $\begin{array}{l}\text { Lumber and bamboo } \\
\text { products }\end{array}$ & 0.9846 & -1.54 & 0.9864 & -1.36 & 0.9983 & -0.17 & 1.0004 & 0.04 & 0.9979 & -0.21 \\
\hline $\begin{array}{l}\text { Paper products and } \\
\text { printing }\end{array}$ & 0.9777 & -2.23 & 0.9873 & -1.27 & 0.9901 & -0.99 & 0.9998 & -0.02 & 0.9904 & -0.96 \\
\hline Chemicals & 0.9792 & -2.08 & 0.9966 & -0.34 & 0.983 & -1.7 & 1.0044 & 0.44 & 0.9784 & -2.16 \\
\hline Rubber products & 1.0132 & 1.32 & 1.0367 & 3.67 & 0.9775 & -2.25 & 1 & 0 & 0.9775 & -2.25 \\
\hline Plastic products & 0.9855 & -1.45 & 1.0123 & 1.23 & 0.9737 & -2.63 & 0.9983 & -0.17 & 0.9754 & -2.46 \\
\hline Non-metallic minerals & 0.9728 & -2.72 & 1.0101 & 1.01 & 0.9629 & -3.71 & 1.0015 & 0.15 & 0.9614 & -3.86 \\
\hline $\begin{array}{l}\text { Basic metals and metal } \\
\text { products }\end{array}$ & 0.9381 & -6.19 & 0.9855 & -1.45 & 0.9517 & -4.83 & 0.988 & -1.2 & 0.9633 & -3.67 \\
\hline $\begin{array}{l}\text { Machinery equipment } \\
\text { products }\end{array}$ & 0.9702 & -2.98 & 0.9874 & -1.26 & 0.9824 & -1.76 & 0.9852 & -1.48 & 0.9972 & -0.28 \\
\hline $\begin{array}{l}\text { Electronic and electric } \\
\text { appliances }\end{array}$ & 1.003 & 0.3 & 1.0127 & 1.27 & 0.9905 & -0.95 & 0.9983 & -0.17 & 0.9918 & -0.82 \\
\hline Transport equipment & 1.0546 & 5.46 & 1.0525 & 5.25 & 1.052 & 0.2 & 1.0149 & 1.49 & 0.9872 & -1.28 \\
\hline Precision instruments & 1.0685 & 6.85 & 1.06 & 6.16 & 140.995 & 0.65 & 1.0114 & 1.14 & 0.9953 & -0.47 \\
\hline Average & 0.9946 & -0.54 & 1.0074 & 0.74 & 0.9874 & -1.26 & 0.9996 & -0.04 & 0.9877 & -1.23 \\
\hline
\end{tabular}


For each time series with $T$ observations and $n$ time period we first implement the ADF test:

$\Delta y_{i t}=a_{i 0}+\gamma_{i} y_{i t-1}+a_{i 2} t+\sum_{j=1}^{P_{i}} \beta_{i j} \Delta y_{i t-j}+\varepsilon_{i t} \quad i=\mathbf{1}, \ldots, N$

The hypothesis is:

$H_{0}: \gamma_{i}=0 \quad(i=1, \ldots, n) \quad$ (with unit root, nonstationary)

$H_{1}: \gamma_{i}<0 \quad(i=1, \ldots, n) \quad$ (without unit root, stationary)

We calculate the average of the individual $t$-test:

$\bar{t}=\left(\frac{1}{n}\right) \sum_{i=1}^{n} t_{i}$

$\bar{t}$ is used to identify the existence of a unit root. If the variable has a unit root, we need to difference the time series until it is stationary. From Table 2 we can see that several OFDI related variables and exports are not stationary. We take first difference on all variables and redo the panel unit root test. According to Table 3 all differenced variables are stationary.

The econometric results with different dependent variables as proxies for competitiveness are shown in Tables 4-10. In each table we present the estimations of three models with alternative outward FDI variables. Model (1) uses total outward FDI, Model (2) uses the proportion of total outward FDI considered expansive and the proportion considered defensive, Model (3) uses the proportion of total outward FDI destined to China and destined to other countries.

Tables 4-10 show that $\Delta \ln M$ (change in imports) is significantly negative in almost all models, indicating that increases in imports may reduce competitiveness. R\&D stock increases impact industrial output growth positively but appear to have no impact on other dependent variables. This could be indicating that the process described in Eq. (3-3) to obtain this variable might not be appropriate as the literature in general indicates longer lags in the construction of this stock. $\Delta \ln X$ (change in exports) has a positive significant impact on GDP share changes. It implies that those industries with rapid increases in exports show a competitive advantage over others resulting in higher GDP industry shares. $\Delta$ ln IFDI (change in inward FDI) is insignificant in all models.

Table 2

Results of the Panel unit root test (I).

\begin{tabular}{ll}
\hline Variables & Statistics \\
\hline GDPCH & $-2.108^{* *}$ \\
GDPSHCH & $-3.122^{* *}$ \\
TFPCH & $-3.662^{* *}$ \\
EFFCH & $-4.298^{* *}$ \\
TECH & $-3.416^{* *}$ \\
PECH & $-4.173^{* *}$ \\
SECH & $-3.031^{* *}$ \\
LnIFDI & $-2.895^{* *}$ \\
LnOFDI & -1.691 \\
LnDOFDI & $-2.031^{* *}$ \\
LnEOFDI & -1.646 \\
LnOFDI_China & $-2.218^{* *}$ \\
LnOFDI_Others & -1.801 \\
LnR\&D & $-4.099^{* *}$ \\
LnX & -0.868 \\
LnM & $-1.908^{*}$ \\
\hline
\end{tabular}

Note: "**' Significance at the $5 \%$ level, '*’ significance at the $10 \%$ level.

Table 3

Results of the Panel unit root test (II).

\begin{tabular}{lc}
\hline Variables & Statistics \\
\hline$\Delta$ LnIFDI & $-3.483^{* *}$ \\
$\Delta$ LnOFDI & $-3.082^{* *}$ \\
$\Delta$ LnDOFDI & $-2.869^{* *}$ \\
$\Delta$ LnEOFDI & $-2.855^{* *}$ \\
$\Delta$ LnOFDI_China & $-2.931^{* *}$ \\
$\Delta$ LnOFDI_Others & $-3.37^{* *}$ \\
$\Delta$ LnX & $-2.605^{* *}$ \\
$\Delta$ LnM & $-3.623^{* *}$ \\
\hline Note: '**' Significance at the 5\% level, '*' significance at the 10\% level.
\end{tabular}


Table 4

Econometric results with output change as dependent variable.

\begin{tabular}{|c|c|c|c|c|c|c|}
\hline \multirow[t]{2}{*}{ Variables } & \multicolumn{2}{|l|}{ Model 1} & \multicolumn{2}{|l|}{ Model 2} & \multicolumn{2}{|l|}{ Model 3} \\
\hline & Coefficients & $T$-ratio & Coefficients & $T$-ratio & Coefficients & $T$-ratio \\
\hline$\Delta$ LnOFDI & -0.0012 & -0.2800 & & & & \\
\hline 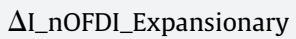 & & & 0.0007 & 0.3970 & & \\
\hline$\Delta$ LnOFDI_Defensive & & & -0.0042 & -0.9390 & & \\
\hline$\Delta$ LnOFDI_China & & & & & -0.0010 & -0.2570 \\
\hline$\Delta$ LnOFDI_others & & & & & 0.0003 & 0.1220 \\
\hline$\Delta \operatorname{LnRD}$ & $0.1018^{* * *}$ & 2.9300 & $0.1050^{* * *}$ & 2.9900 & $0.1006^{* * *}$ & 2.8600 \\
\hline$\Delta \mathrm{LnM}$ & $-0.2368^{* * *}$ & -4.4000 & $-0.2267^{* * *}$ & -4.1600 & $-0.2359^{* * *}$ & -4.3300 \\
\hline$\Delta \operatorname{LnX}$ & 0.0417 & 0.9300 & 0.0338 & 0.7420 & 0.0423 & 0.9390 \\
\hline$\Delta$ LnlFDI & 0.0026 & 0.8800 & 0.0024 & 0.00 & 0.0023 & 0.6780 \\
\hline Constant & $0.0587^{* * *}$ & 2.4280 & & & $0.0585^{* * *}$ & 2.4170 \\
\hline Wald $X^{2}$ & $151.2749^{* * *}$ & & $152.3505^{* * *}$ & & 149.7546 & \\
\hline Buse $R^{2}$ & 0.5827 & & 0.5841 & & 0.5811 & \\
\hline Buse row moment $R^{2}$ & 0.6007 & & 0.6029 & & 0.5981 & \\
\hline
\end{tabular}

Note: “*” Significance at the $10 \%$ level, “**” significance at the $5 \%$ level, “***” significance at the $1 \%$ level.

As to outward FDI, Tables 4 and 5 show that the outward FDI variables have no influence on either industrial output growth or GDP share. This implies that, when industry competitiveness is approximated by these variables, the outflow of industrial investments does not affect a particular industry's competitiveness relative to others. However, outward FDI does have a significant negative impact on productivity change (Table 6). It also has a significant and opposite effect on technical

Table 5

Econometric results with GDP share change as dependent variable.

\begin{tabular}{|c|c|c|c|c|c|c|}
\hline \multirow[t]{2}{*}{ Variables } & \multicolumn{2}{|l|}{ Model 1} & \multicolumn{2}{|l|}{ Model 2} & \multicolumn{2}{|l|}{ Model 3} \\
\hline & Coefficients & $T$-ratio & Coefficients & $T$-ratio & Coefficients & $T$-ratio \\
\hline$\Delta$ LnOFDI & 0.0008 & 0.2630 & & & & \\
\hline$\Delta$ LnOFDI Defensive & & & -0.0013 & -0.4250 & & \\
\hline$\Delta$ LnOFDI China & & & & & 0.0001 & 0.0434 \\
\hline$\Delta$ LnOFDI others & & & & & 0.0003 & 0.1650 \\
\hline$\Delta \mathrm{LnRD}$ & 0.0282 & 1.1200 & 0.0311 & 1.2200 & 0.0286 & 1.1200 \\
\hline$\Delta \mathrm{LnM}$ & $-0.1837^{* * *}$ & -4.5800 & $-0.1758^{* * *}$ & -4.3100 & $-0.1813^{* * *}$ & -4.4500 \\
\hline$\Delta \operatorname{LnX}$ & $0.0918^{* * *}$ & 2.6500 & $0.0853^{* *}$ & 2.4300 & $0.0901^{* *}$ & 2.6000 \\
\hline$\Delta$ LnlFDI & 0.0026 & 1.2400 & 0.0026 & 1.2200 & 0.0025 & 1.0300 \\
\hline Constant & 0.0054 & 0.2418 & 0.0043 & 0.1925 & 0.00540 & 0.2237 \\
\hline Wald $X^{2}$ & $187.5221^{* * *}$ & & $187.7944^{* * *}$ & & $187.4192^{* * *}$ & \\
\hline Buse $R^{2}$ & 0.6370 & & 0.6361 & & 0.6367 & \\
\hline Buse row moment $R^{2}$ & 0.7464 & & 0.7425 & & 0.7453 & \\
\hline
\end{tabular}

Note: “*” Significance at the $10 \%$ level, “**” significance at the $5 \%$ level, "***” significance at the $1 \%$ level.

Table 6

Econometric results with TFP change as dependent variable.

\begin{tabular}{|c|c|c|c|c|c|c|}
\hline \multirow[t]{2}{*}{ Variables } & \multicolumn{2}{|l|}{ Model 1} & \multicolumn{2}{|l|}{ Model 2} & \multicolumn{2}{|l|}{ Model 3} \\
\hline & Coefficients & T-ratio & Coefficients & T-ratio & Coefficients & T-ratio \\
\hline$\Delta$ LnOFDI & $-0.2235^{* * *}$ & -6.2300 & & & & \\
\hline$\Delta$ LnOFDI_Expansionary & & & 0.0055 & 0.3780 & & \\
\hline$\Delta$ LnOFDI_Defensive & & & $-0.2274^{* * *}$ & -6.3100 & & \\
\hline$\Delta$ LnOFDI_China & & & & & $-0.1884^{* * *}$ & -6.0200 \\
\hline$\Delta$ LnOFDI_others & & & & & -0.0158 & -0.8420 \\
\hline$\Delta \mathrm{LnM}$ & -0.6079 & -1.6100 & -0.5956 & -1.6300 & $-0.6344^{*}$ & -1.6800 \\
\hline$\Delta \mathrm{LnX}$ & -0.3989 & -1.3100 & -0.4247 & -1.4200 & -0.3382 & -1.4200 \\
\hline$\Delta$ LnlFDI & 0.0288 & 1.2700 & 0.0239 & 1.3300 & 0.0359 & 1.3300 \\
\hline Constant & $1.3775^{* * *}$ & 12.0700 & $1.3706^{* * *}$ & 12.0100 & $1.3667^{* * *}$ & 12.0500 \\
\hline Wald $X^{2}$ & 13.1368 & & 13.1698 & & 11.6517 & \\
\hline Buse $R^{2}$ & 0.3368 & & 0.3488 & & 0.3314 & \\
\hline Buse row moment $R^{2}$ & 0.9589 & & 0.95 & & 0.9589 & \\
\hline
\end{tabular}

Note: “*” Significance at the $10 \%$ level, “**” significance at the 5\% level, “***” significance at the $1 \%$ level. 
Table 7

Econometric results with technical change as dependent variable.

\begin{tabular}{|c|c|c|c|c|c|c|}
\hline \multirow[t]{2}{*}{ Variables } & \multicolumn{2}{|l|}{ Model 1} & \multicolumn{2}{|l|}{ Model 2} & \multicolumn{2}{|l|}{ Model 3} \\
\hline & Coefficients & $T$-ratio & Coefficients & T-ratio & Coefficients & $T$-ratio \\
\hline$\Delta$ LnOFDI & $-0.2636^{* * *}$ & -8.4020 & & & & \\
\hline$\Delta$ LnOFDI Defensive & & & $-0.2452^{* * *}$ & -7.7000 & & \\
\hline$\Delta$ LnOFDI China & & & & & $-0.2167^{* * *}$ & -7.9000 \\
\hline$\Delta$ LnOFDI others & & & & & -0.0200 & -1.1400 \\
\hline$\Delta \mathrm{LnRD}$ & 0.0526 & 0.2839 & 0.0349 & 0.1900 & 0.1236 & 0.6540 \\
\hline$\Delta \mathrm{LnM}$ & -0.2983 & -0.9536 & -0.2627 & -0.8440 & -0.3410 & -1.0800 \\
\hline$\Delta \operatorname{LnX}$ & -0.3236 & -1.2840 & -0.3320 & -1.3300 & -0.2837 & -1.3300 \\
\hline$\Delta$ LnlFDI & 0.0158 & 0.7903 & 0.0095 & 0.4420 & 0.0226 & 0.9220 \\
\hline Constant & $1.3165^{* * *}$ & 16.3400 & & & $1.3140^{* *}$ & 15.9000 \\
\hline Wald $X^{2}$ & 15.7329 & & 15.6923 & & 14.3962 & \\
\hline Buse $R^{2}$ & 0.4381 & & 0.4324 & & 0.4265 & \\
\hline Buse row moment $R^{2}$ & 0.9671 & & 0.966 & & 0.9663 & \\
\hline
\end{tabular}

Note: “*” Significance at the $10 \%$ level, “**” significance at the $5 \%$ level, “***” significance at the $1 \%$ level.

change and efficiency change (Tables 6 and 8). FDI outflows impact the innovation component negatively resulting in deterioration of overall productivity change. A look at model 2 identifies defensive outward FDI as the main component of this effect (expansionary outward FDI is not significant). Model 3 shows that outward FDI destined to China can be associated with this significant negative impact. It is also interesting to note the effect of outward FDI on technical efficiency change. If

Table 8

Econometric results with efficiency change as dependent variable.

\begin{tabular}{|c|c|c|c|c|c|c|}
\hline \multirow[t]{2}{*}{ Variables } & \multicolumn{2}{|l|}{ Model 1} & \multicolumn{2}{|l|}{ Model 2} & \multicolumn{2}{|l|}{ Model 3} \\
\hline & Coefficients & $T$-ratio & Coefficients & $T$-ratio & Coefficients & $T$-ratio \\
\hline$\Delta$ LnOFDI & $0.0499^{* * *}$ & 3.7000 & & & & \\
\hline$\Delta$ LnOFDI_Expansionary & & & 0.0002 & 0.0344 & & \\
\hline$\Delta$ LnOFDI Defensive & & & $0.0429^{* * *}$ & 3.0300 & & \\
\hline$\Delta$ LnOFDI China & & & & & 0.0445 & 0.8420 \\
\hline$\Delta$ LnOFDI others & & & & & $-0.0039^{* * *}$ & -4.2500 \\
\hline$\Delta \mathrm{LnRD}$ & 0.0552 & 0.8570 & 0.0663 & 1.0100 & 0.0556 & 1.4200 \\
\hline$\Delta \mathrm{LnM}$ & $-0.7599^{* * *}$ & -4.0100 & $-0.7711^{* * *}$ & -3.9600 & $-0.8064^{* * *}$ & 3.6400 \\
\hline$\Delta \operatorname{LnX}$ & 0.1849 & 1.2200 & 0.1849 & 0.5900 & 0.2177 & -0.5900 \\
\hline$\Delta$ LnlFDI & 0.0073 & 0.7010 & 0.0082 & 0.7550 & 0.0107 & 0.9506 \\
\hline Constant & $1.1945^{* * *}$ & 11.3100 & $1.1956^{* * *}$ & 11.2300 & $1.2015^{* * *}$ & 11.3000 \\
\hline Wald $X^{2}$ & 8.5079 & 0.8612 & 8.7619 & 0.8460 & 10.2313 & 0.7451 \\
\hline Buse $R^{2}$ & 0.2795 & & 0.2532 & & 0.2755 & \\
\hline Buse row moment $R^{2}$ & 0.9901 & & 0.9895 & & 0.9899 & \\
\hline
\end{tabular}

Note: “*” Significance at the $10 \%$ level, “**” significance at the $5 \%$ level, “***” significance at the $1 \%$ level.

Table 9

Econometric results with pure efficiency change as dependent variable.

\begin{tabular}{|c|c|c|c|c|c|c|}
\hline \multirow[t]{2}{*}{ Variables } & \multicolumn{2}{|l|}{ Model 1} & \multicolumn{2}{|l|}{ Model 2} & \multicolumn{2}{|l|}{ Model 3} \\
\hline & Coefficients & $T$-ratio & Coefficients & $T$-ratio & Coefficients & $T$-ratio \\
\hline$\Delta$ LnOFDI & $0.0101^{* * *}$ & 3.4500 & & & & \\
\hline$\Delta$ LnOFDI_Defensive & & & $0.0072^{* *}$ & 2.2600 & & \\
\hline$\Delta$ LnOFDI_China & & & & & 0.0042 & 1.5300 \\
\hline$\Delta$ LnOFDI_others & & & & & 0.0012 & 0.7830 \\
\hline$\Delta \operatorname{LnRD}$ & -0.0213 & -1.6000 & -0.0144 & -1.040 & -0.013 & -0.9680 \\
\hline$\Delta \mathrm{LnM}$ & $-0.1010^{* * *}$ & -2.4400 & $-0.1160^{* * *}$ & -2.6700 & $-0.0944^{* *}$ & -2.2300 \\
\hline$\Delta \mathrm{LnX}$ & 0.0326 & 0.9710 & 0.0386 & 1.0700 & 0.0272 & 0.7760 \\
\hline$\Delta$ LnlFDI & 0.0018 & 0.8010 & 0.0015 & 0.6020 & 0.0013 & 0.4640 \\
\hline Constant & $1.0791^{* * *}$ & 20.8600 & $1.0802^{* * *}$ & 21.3400 & $1.0774^{* * *}$ & 20.9800 \\
\hline Wald $X^{2}$ & 5.3810 & 0.9798 & 5.8591 & 0.9699 & 5.1051 & 0.9843 \\
\hline Buse $R^{2}$ & 0.1826 & & 0.1546 & & 0.1177 & \\
\hline Buse row moment $R^{2}$ & 0.9995 & & 0.9994 & & 0.9994 & \\
\hline
\end{tabular}

Note: “*” Significance at the $10 \%$ level, “**” significance at the $5 \%$ level, “***” significance at the $1 \%$ level. 
Table 10

Econometric results with scale efficiency change as dependent variable.

\begin{tabular}{|c|c|c|c|c|c|c|}
\hline \multirow[t]{2}{*}{ Variables } & \multicolumn{2}{|l|}{ Model 1} & \multicolumn{2}{|l|}{ Model 2} & \multicolumn{2}{|l|}{ Model 3} \\
\hline & Coefficients & T-ratio & Coefficients & T-ratio & Coefficients & T-ratio \\
\hline$\Delta$ LnOFDI & $0.0374^{* * *}$ & 3.0500 & & & & \\
\hline$\Delta$ LnOFDI_Expansionary & & & 0.0000 & 0.0054 & & \\
\hline$\Delta$ LnOFDI_Defensive & & & $0.0325^{* * *}$ & 2.5700 & & \\
\hline$\Delta$ LnOFDI_China & & & & & $0.0352^{* * *}$ & 3.2400 \\
\hline$\Delta$ LnOFDI_others & & & & & -0.0041 & -0.7290 \\
\hline$\Delta \mathrm{LnRD}$ & 0.0667 & 1.1900 & $0.0738^{* * *}$ & 1.3000 & 0.0667 & 1.1500 \\
\hline$\Delta \mathrm{LnM}$ & $-0.5345^{* * *}$ & -3.1600 & $-0.5491^{*}$ & -3.1900 & $-0.5766^{* * *}$ & -3.4100 \\
\hline$\Delta \operatorname{LnX}$ & 0.0282 & 0.2150 & 0.0342 & 0.4410 & 0.0585 & 0.4410 \\
\hline$\Delta$ LnlFDI & 0.0057 & 0.6450 & 0.0068 & 0.7420 & 0.0097 & 1.0000 \\
\hline Constant & 1.0708 & 0.0591 & $1.0720^{* * *}$ & 17.8100 & $1.0766^{* * *}$ & 18.0600 \\
\hline Wald $X^{2}$ & 4.7479 & & 5.0106 & & 5.8520 & \\
\hline Buse $R^{2}$ & 0.2400 & & 0.9699 & & 0.2519 & \\
\hline Buse row moment $R^{2}$ & 0.9925 & & 0.9923 & & 0.9926 & \\
\hline
\end{tabular}

Note: “*” Significance at the 10\% level, “**” significance at the 5\% level, “***” significance at the $1 \%$ level.

outward defensive FDI is taken as a means of decreasing costs to improve operational efficiency and therefore competitiveness of the industry, then our results in Tables 8-10 suggest that there are some industries doing so, perhaps by successfully reallocating resources toward a more efficient production scale. The results in Table 6 though indicate that the negative effect on innovation overshadows the positive efficiency effect.

Previous literature (Hsiao \& Hsiao, 2006, among others) suggests that there might be a causal relationship between the dependent variables and the explanatory variables when using either productivity change or output growth. Since our main interest is to identify the impact of outward FDI on domestic industries' competitiveness, we conduct a panel GrangerCausality test between each outward FDI variable and all of the dependent variables to identify potential causation. The panel Granger-Causality test is implemented by estimating the following system equations:

$\Delta y_{i t}=\alpha_{i}+\sum_{m=1}^{M} \beta_{m} \Delta x_{t-m}+\sum_{n=1}^{N} \gamma_{n} \Delta y_{t-n}+\mu_{i t}$

$\Delta x_{i t}=\delta_{i}+\sum_{p=1}^{P} \phi_{p} \Delta x_{t-p}+\sum_{s=1}^{S} \rho_{s} \Delta y_{t-s}+v_{i t}$

where $\Delta y$ is one of the six dependent variables and $\Delta x$ is one of the five specifications of the outward FDI variables. $\alpha, \delta$ are individual intercepts for each industry estimated using fixed effect. Akaike Information Criterion (AIC) is used to identify the optimal lag length of three periods. The results of the Granger-Causality test are reported in Table 11 . Five main points emerge from this table.

1. There is no Granger-Causality between outward FDI (both aggregate and decomposed outward FDI) and industrial real output growth (GDPCH). This result is consistent with the result from Table 3.

2. While Table 5 shows no effect from any one of the OFDI categories on industrial GDP share, Table 11 indicates that expansionary outward FDI, i.e. outward FDI destined to China and to other countries, cause reduction of the industrial domestic GDP share. It implies that, if competitiveness is measured by GDP share, then industrial competitiveness was weakened resulting on declining GDP shares. These results also indicate that deteriorating competitiveness, or a lower GDP share, might be inducing defensive FDI, and FDI to China may be a means of improving efficiency through cost savings.

3. No matter the type of outward FDI, they all Granger-cause a deterioration of total factor productivity change but the opposite is not always true. An increase in industrial productivity only Granger-causes an outflow of capital investment to other countries.

4. Expansionary outward FDI and outward FDI to other countries cause improvement in industrial technical change, while other sources of outward FDI including defensive outward FDI and that destined to China impact innovation negatively. We speculate that defensive FDI (and in particular to China) might have been undertaken to maintain competitiveness in industries that would benefit from efficiency improvements through reallocation that results in lower costs. A technical change improvement may slow down total outflow of capital investments. This causation effect is affected when outward FDI to China is disaggregated from total OFDI. Innovations in Taiwanese industries induce outward FDI destined to other countries.

5. Almost all of the outward FDI Granger-causes changes in industries' efficiency performance. The reverse causation is not so clear. 


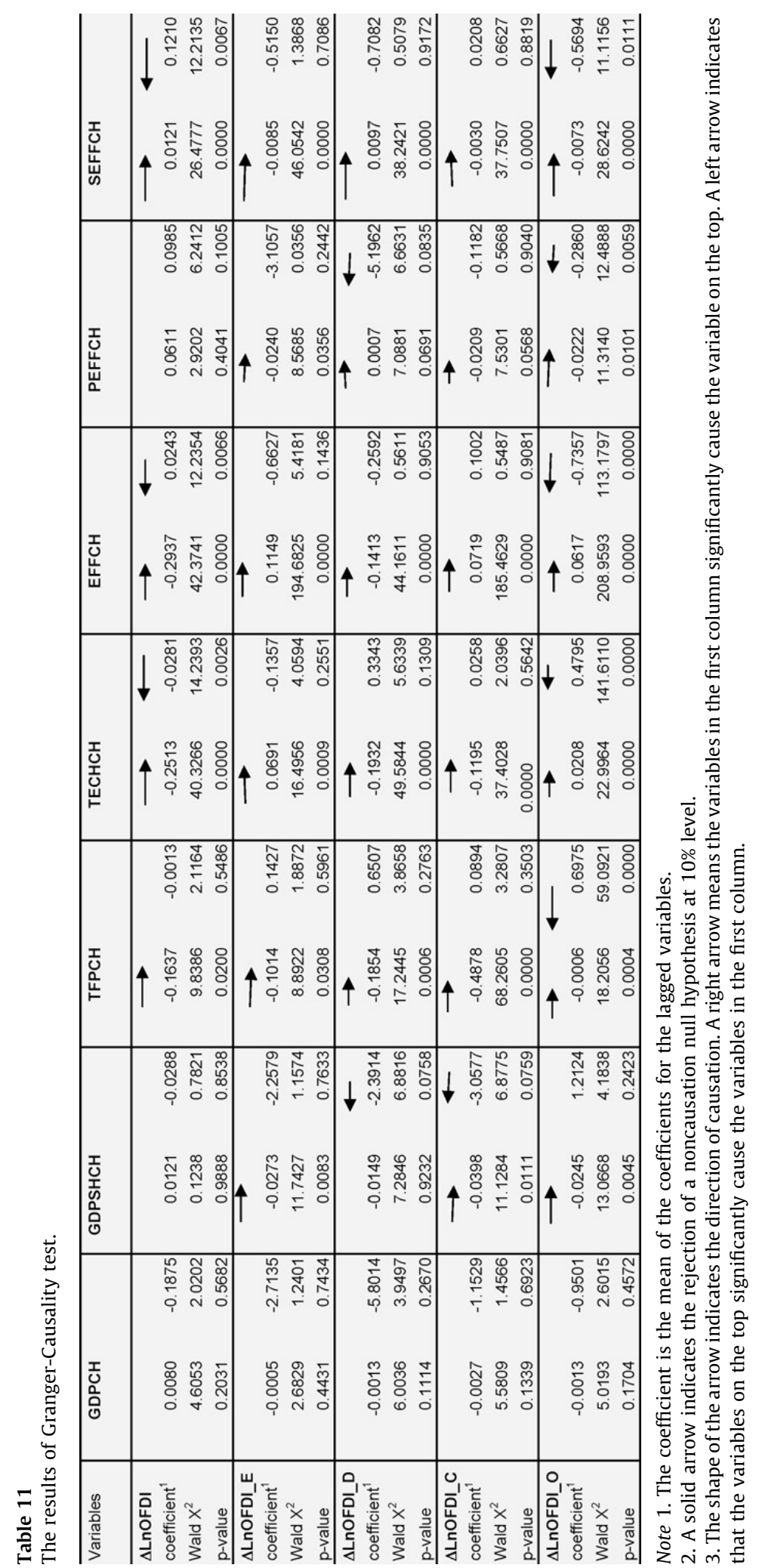


Table 12

Summary of the impact of OFDI in Taiwan's industrial competitiveness.

\begin{tabular}{|c|c|c|c|c|c|c|c|}
\hline Variables & GDPCH & GDPSHCH & TFPCH & TECHCH & EFFCH & PEFFCH & SEFFCH \\
\hline OFDI & NA & NA & -- & -- & +- & + & ++ \\
\hline OFDI_E & NA & - & - & + & + & - & - \\
\hline OFDI_D & NA & NA & -- & -- & +- & ++ & ++ \\
\hline OFDI_C & NA & - & -- & -- & + & - & +- \\
\hline OFDI_O & NA & - & -- & + & -+ & - & - \\
\hline
\end{tabular}

Note: 1. "+" represents a significant positive impact from the corresponding OFDI variable to the variable on the top.

2."-" represents a deteriorating impact from the related OFDI variable to the competitiveness criteria.

3."+-" represents ambiguous impacts with positive impact in one model and one negative impact in the other.

4. "NA" indicates no impact from either model.

5. If there is only one symbol inside the cell indicates that there is only one significant result from either single equation estimation or causality model.

Table 12 summarizes results on the impacts of outward FDI on Taiwan's industrial competitiveness captured by three different concepts, output growth, GDP share growth and productivity growth. A significant positive impact from outward FDI is represented by a "+", a negative by "-", ambiguity by a "+ -" and if no impact is detected "NA" is used. Only one symbol in the cell indicates that there is only one significant result, either from the single equation model or the causality model. Outward FDI, expansionary and that destined to China or other countries, reduces GDP shares of the industries. Defensive OFDI affects industrial innovation negatively while it improves industry efficiency with an overall negative impact on productivity change.

Our results indicate that outward FDI, especially of the defensive type, has impacted innovation of domestic industries negatively. We also find that outward FDI to China improved efficiency of some industries, probably those that were decreasing international market share, by allowing cost improvements channeled through reallocations that resulted in scale changes. The net effect of outward FDI on industrial productivity change though seems to have been a slow down on innovation and growth and in this sense a decrease in industrial competitiveness.

\section{Conclusion}

Earlier FDI studies primarily focused on FDI inflows. Some studies did look into the impact of outward FDI on the home countries' economy but they did not distinguish between type of outward FDI, defensive or expansionary. This study focuses on the impact of different categories of outward FDI on the Taiwanese industry. This is important given the prevalence of defensive FDI in general and that destined to China and other newly industrialized countries in the latter years.

The Malmquist productivity index shows that from 1992 to 2001 the average annual TFP growth rate for 15 Taiwanese industries was $-0.54 \%$. Efficiency of the industry has suffered during this period while innovations have ameliorated this effect. Econometric results indicate that outward FDI has no influence on industry's output growth and on industries' GDP share. Defensive outward FDI has had significant negative influence on technical change which has been ameliorated by its positive effect on industry efficiency. The overall impact on productivity though being negative might cause deterioration in the international competitiveness of the Taiwanese industry. Outward FDI destined to China has had no effect on output growth, nor on industry shares, but has had a significant negative impact on innovations and a significant positive impact on scale efficiency with an overall negative impact on industrial productivity change.

This research highlights the importance of incorporating in an analysis of industry competitiveness different types of outward FDI. It also shows the importance of alternative approximations to the concept of competitiveness. The literature is by no means clear about this concept with the result that different proxies lead to different conclusions. We have used three concepts, output growth, growth of GDP shares, and productivity growth to proxy industry competitiveness. Impact of outward FDI is by no means identical across these proxies. This study shows that outward FDI, in particular destined to China, has improved efficiency of some industries but has resulted in slower innovative activity. If competitiveness is synonymous with productivity, then this type of outward FDI during 1991-2001 resulted in a deterioration of Taiwanese industry competitiveness.

\section{References}

Blomström, M., Fors, G., \& Lipsey, R. E. (1997). Foreign Direct Investment and Employment: Home Country Experience in the United States and Sweden. The Economic Journal, 107(445), 1787-1797.

Brooks, D. H., Roland-Holst, D., \& Zhai, F. (2008). Behavioral and empirical perspectives on FDI: International capital allocation across Asia. Journal of Asian Economics, 19(1), 40-52.

Caves, D. W., Christensen, L. R., \& Diewert, W. E. (1982a). Multilateral comparison of output and productivity using superlative index numbers. Economic Journal, $92,73-86$.

Caves, D. W., Christensen, L. R., \& Diewert, W. E. (1982b). The economic theory of index numbers and the measurement of input, output and productivity. Economitrica, 50, 1393-1414.

Caves, R. E. (1974). Multinational firms, competition, and productivity in host-country markets. Economica, 35(4), $117-137$.

Chang, C. C., \& Luh, Y. H. (2000). Efficiency change and growth in productivity: The Asian growth experience. Journal of Asian Economics, 10, 551-570. 
Chen, T.-J., \& Ku, Y. H. (2000). The effect of foreign direct investment on firm growth: The case of Taiwan's manufacturers. Japan and the World Economy, 12, 153172.

Coelli, T., Prasada Rao, D. S., O’Donnell, C. J., \& Battese, G. E. (2005). An introduction to efficiency and productivity analysis. LLC: Springer Science+Business Media. Edwards, Sebastian. (1993). Openness, trade liberalization, and growth in developing countries. Journal of Economic Literature, 31 (3), $1358-1393$.

Edwards, Sebastian. (1998). Openness, Productivity and Growth: What Do we Really Know? The Economic Journal, 108(March), $383-398$.

Färe, R., Shawna, G., Bjorn, L., \& Pontus, R. (1989). Productivity developments in Swedish hospitals: A Malmqvist output index approach. memo .

Färe, Rolf, Grosskopf, S., \& Lovell, K. (1994). Production fronties. Ambridge: Cambridge Univ Press.

Färe, R., Grosskopf, S., Norris, M., \& Zhang, Z. (1994). Productivity growth, technical progress, and efficiency changes in industralized countries. American Economic Review. March 1994, 84(1), 66-83.

Farrell, M. J. (1957). The measurement of productive efficiency. Journal of Royal Statistical Society, 120, $253-281$.

Frankel, J. A., \& Romer, D. (1999). Does trade cause growth. The American Economic Review, June, 379-399.

Grossman, G.M., \& Helpman, E. Trade, Knowledge Spillovers, and Growth. NBER working papers series, No. 3485, October 1990.

Haddad, M., \& Harrison, A. (1993). Are there positive spillovers from direct foreign investment? Evidence from panel data for Morocco. Journal of Development Economics, 42, 51-74.

Hsiao, F. S. T., \& Hsiao, M.-C.W. (2006). FDI, exports, and GDP in East and Southeast Asia-panel data versus time-series causality analyses. Journal of Asian Economics, 17(6), 1082-1106.

Hymer, S. H. (1960). The international operations of national firms: A study of direct foreign investment, Ph.D. Thesis, MIT, MIT Press, Cambridge, MA.

Im, K. S., Pesaran, M. H., \& Shin, Y. (2003). Testing unit roots in heterogeneous panels. Journal of Econometrics, 115, 53-74.

Lawrence, R. Z., \& Weinstein, D. E. (1999). “Trade and Growth: Import-Led or Export-Led? Evidence From Japan and Korea”, NBER working Paper Series, No. 7264, National Bureau of Economic Research.

Lichtenberg, F., \& Van Pottelsberghe de la Potterie, B. (1996). International RED Spillovers: A Re-Examination, NBER Working paper series, No 5668.

Lipsey, R.E. Outward Direct Investment and the U.S. Economy (March 1994). NBER Working Paper, No. W4691. Available at SSRN: http://ssrn.com/ abstract=254558.

Lipsey, Ramstetter, \& Blomstrom, 2000. “Outward FDI and Parent Exports and Employment: Japan, the United States, and Sweden”. NBER Working Paper, No. 7623, March 2000.

Malmquist, S. (1953). Index numbers and indifference surfaces. Trabajos de Estatistica, 4, 209-242.

Makki, S., \& Somwaru, A. (2004). Impact of Foreign Direct Investment and Trade on Economic Growth: Evidence from Developing Countries. American Journal of Agricultural Economics, 86, 795-801.

Nachum, L., Jones, G. G., \& Dunning, J. H. (2001). The international competitiveness of the UK and its multinational enterprises. Structural Change and Economic Dynamics, 12, 277-294.

Ng, L.F.-Y., \& Tuan, C. (2006). Spatial agglomeration, FDI, and regional growth in China: Locality of local and foreign manufacturing investments. Journal of Asian Economics, 17(4), 691-713.

Oxelheim, L., \& Ghauri, P. (2008). EU-China and the non-transparent race for inward FDI. Journal of Asian Economics, 19(4), 358-370.

Porter, M. E. (1985). Competitive advantage. New York: Free Press.

Raut, L. K. (1995). R\&D spillover and productivity growth: Evidence from Indian private firms. Journal of Development Economics, $48,1-23$.

Rodrik, D. (1999). The new global economy and developing countries: Making openness work. Washington DC: Overseas Development Council.

Vernon, R. (1966). International investment and international trade in the product cycle. Ouarterly Journal of Economics, 80(4), 190-207.

Yanikkaya, H. (2003). Trade openness and economic growth: a cross-country empirical investigation. Journal of Development Economics, 72(2003), 57-89. 